\title{
PENGARUH PURSED LIPS BREATHING TERHADAP PEAK EXPIRATORY FLOW RATE PENDERITA PENYAKIT PARU OBSTRUKSI KRONIS
}

Emdat Suprayitno, Program Studi Ners UNIJA Sumenep

e-mail: emdats@yahoo.com

\section{ABSTRACT}

Chronic obstructive pulmonary disease (COPD) is a public health problem. Shortness of breath is a major problem on patient COPD. The shortness of breath caused decrease of PEF value. The intervention can be done to patients COPD is pursed lips breathing exercise.

The method of this research was true experiment, pretest-posttest design with control group involving 30 respondents with random sampling. Treatment group were 15 respondents that provided PLB exercise three times a week for 4 weeks. Control group were 15 respondents that only getting standard treatment from the hospital. Data analysis was performed with paired test test and independent $t$ test.

The results of paired t test on PEF value are $p=0.000$ for intervention group and $p=0.334$ for control groups. The result of independent $t$ test in intervention and control groups PEF value $p=$ 0.000 .

There was influence pursed lips breathing exercise to increased PEF value. There was difference PEF value on treatment group and control group after pursed lips breathing exercise.

Keywords: chronic obstruction pulmonary disease (COPD), Self efficacy, Self management, Pursed lips breathing (PLB)

\section{PENDAHULUAN}

Penyakit paru obstruksi kronik (PPOK) adalah salah satu dari jenis penyakit tidak menular yang sudah menjadi permasalahan dalam kesehatan masyarakat di dunia. Masalah ini bukan hanya bagi negara maju namun juga bagi negara berkembang seperti Indonesia (Depkes, 2008). Berdasarkan data WHO tahun 2010 PPOK merupakan masalah kesehatan utama yang menyebabkan kematian peringkat ke empat di Indonesia (PDPI, 2016). Sesak nafas adalah masalah yang paling sering dijumpai pada penderita PPOK (Ambrosino et al, 2006). Berdasarkan data rekam medis didapatkan data 10 penyakit terbanyak pada tahun 2013 di Rumah sakit Asy-Syaafi kabupaten Pamekasan pada unit rawat jalan adalah 577 pasien bronchitis dan 504 pasien PPOK. Data pada unit rawat inap jumlah pasien PPOK mencapai 352 pasien yang menjadi jumlah terbanyak kedua setelah tuberculosis yaitu 623 pasien. Rata-rata jumlah kunjungan pasien PPOK selama 3 bulan terakhir yaitu pada bulan Maret, April dan Mei tahun 2016 mencapai 80 pasien (Karina, 2016).

Penderita PPOK sering mengalami penurunan ventilasi alveolus yang membawa dampak terjadinya hipoksemia, hipoksia dan hiperkapnia sehingga menyebabkan asidosis respiratorik yang meningkatkan proses pernafasan dan penggunaan otot-otot bantu pernafasan (Smeltzer et al. 2006). Hipoksia yang terjadi di dalam tubuh akan menyebabkan hipoksia terhadap otot juga, sehingga akan terjadi metabolisme anaerob yang dapat menghasilkan asam laktat yang menyebabkan kelelahan otot. Kelelahan otot yang terjadi di saluran pernafasan dapat menurunkan proses pernafasan (Guyton et al, 2007). Keadaan tersebut mengakibatkan pasien PPOK mengalami ketidakmampuan mendasar untuk mencapai nilai normal aliran udara ketika ekspirasi (Price et al, 2005). Ketidakmampuan dalam mencapai udara normal akibat adanya obstruksi pernapasan dapat mengakibatkan paru-paru mudah mengempis, sehingga terjadi penurunan aliran puncak ekspirasi (Guyton et al, 2007). Peak expiratory flow rate (PEF) atau arus puncak ekspirasi merupakan pencapaian aliran udara tertinggi pada saat ekspirasi serta gambaran perubahan ukuran jalan nafas yang semakin membesar. Menurut Iglesia (2004) PEF digunakan sebagai prediktor kematian rawat inap pasien PPOK yang penting dalam memprediksi kematian pada pasien PPOK.

Penurunan nilai PEF yang menggambarkan adanya penurunan fungsi ventilasi pada pasien PPOK sangat penting dilakukan penanganan. Penatalaksaan untuk pasien dengan PPOK berupa tindakan untuk menghilangkan obstruksi saluran pernafasan nafas kecil (Price et al, 2005). Penatalaksanaan medis maupun keperawatan pada pasien PPOK berguna dalam meminimalkan sesak nafas, menunda terjadinya eksaserbasi yang berulang-ulang, mencegah penurunan fungsi paru-paru dan meningkatkan quality of life (PDPI, 2016). Salah satu bentuk intervensi 
yang dapat diberikan pada pasien PPOK adalah rehabilitasi dengan melaksanakan latihan pernafasan. Latihan pernafasan yang dapat diterapkan pada pasien dengan PPOK salah satunya adalah pursed lips breathing exercise (PDPI, 2016). Pursed lips breathing (PLB) adalah cara yang bisa digunakan dalam bernafas secara efektif dan kemungkinan memperoleh oksigen yang dibutuhkan. PLB mengajarkan untuk mebhembuskan nafas lebih pelan yang memudahkan bernafas dan nyaman pada saat beristirahat atau beraktifitas (Tiep et al, 2005).

\section{BAHAN DAN CARA PNELITIAN}

Penelitian ini merupakan True eksperiment dengan design pretest dan post test with control group. Tujuan penelitian ini adalah mengetahui pengaruh latihan pursed lips breathing (PLB) terhadap peak expiratory flow rate penderita PPOK. Populasi dalam penelitian 160 pasien PPOK dengan teknik random sampling didapatkan sampel 30 responden dengan kriteria inklusi: Pasien PPOK bukan rawat inap, dapat berkomunikasi verbal dengan baik, tidak menderita kanker paru. Kriteria eksklusi yaitu: Responden yang mengundurkan diri menjadi subyek penelitian, mengalami gagal nafas dan mengalami nyeri dada. Penelitian ini membagi responden kedalam 2 kelompok. Kelompok intervensi diberikan latiihan PLB $3 x$ seminggu selama 4 minggu. Kelompok kontrol hanya mendapatkan terapi standar pengobatan dari rumah sakit. Alat ukur yang digunakan adalah Peak flow meter Vitalograph dengan standard kalibrasi ISO 23747:2007 untuk mengukur nilai PEF. nilai PEF. Analisis yang digunakan dalam penelitian menggunakan uji paired test dan independent $t$ test

\section{HASIL PENELITIAN}

Tabel 1. Perbedaan rata-rata nilai PEF sebelum dan setelah PLB kelompok kontrol dan kelompok intervensi

\begin{tabular}{cccc}
\hline \multirow{2}{*}{ Kelompok } & Sebelum & Setelah & $\mathrm{P}$ value \\
\cline { 2 - 4 } & Mean \pm SD & Mean \pm SD & $95 \% \mathrm{Cl}$ \\
\hline \multirow{2}{*}{ Perlakuan } & \multirow{2}{*}{$148.6 \pm 47.4$} & \multirow{2}{*}{$162 \pm 50$} & 0.000 \\
& & $16-10$ \\
\hline \multirow{2}{*}{ Kontrol } & \multirow{2}{*}{$154 \pm 48.9$} & \multirow{2}{*}{$153.3 \pm 49.3$} & 0.334 \\
& & & $0.7-2$ \\
\hline
\end{tabular}

Berdasarkan tabel 1 rata-rata nilai PEF sebelum edukasi self management dan latihan PLB kelompok intervensi yaitu 148.6 \pm 47.4 dan kelompok kontrol yaitu $154 \pm 48.9$. Rata-rata nilai PEF setelah edukasi self management dan latihan PLB kelompok intervensi yaitu $162 \pm 50$ dan kelompok kontrol yaitu 153.3 \pm 49.3 . Hasil analisa uji paired $t$ test kelompok intervensi menunjukkan nilai $\mathrm{p}=0.000$ dan kelompok kontrol menunjukkan nilai $\mathrm{p}=0.334$ berarti terdapat pengaruh PLB terhadap peningkatan nilai PEF kelompok intervensi.

Tabel 2 Perbedaan selisih (delta) rata-rata nilai PEF sebelum dan setelah dilakukan PLB di RSU Asy-Syaafi Pamekasan

\begin{tabular}{|c|c|c|c|}
\hline Variabel & Kelompok & Mean \pm SD & $\begin{array}{l}\mathrm{P} \text { value } \\
95 \% \mathrm{Cl}\end{array}$ \\
\hline \multirow{2}{*}{ PEF } & Perlakuan & $13.33 \pm 4.88$ & 0.000 \\
\hline & Kontrol & $1.33 \pm 3.51$ & $11.48-17.84$ \\
\hline
\end{tabular}

Berdasarkan tabel 2 hasil analisa uji independent $t$ test nilai PEF $\mathrm{p}=0.000$ yang menunjukkan adanya perbedaan signifikan nilai PEF pada kelompok intervensi dan kelompok kontrol sebelum dan sesudah dilakukan PLB.

\section{PEMBAHASAN}

1. Perbedaan rata-rata nilai PEF sebelum dan setelah PLB pada kelompok intervensi dan kelompok kontrol.

Berdasarkan hasil analisa uji paired t test nilai $p=0.000$ pada kelompok intervensi dan $p=$ 0.900 pada kelompok kontrol. Tujuan latihan PLB adalah mengurangi sesak nafas, memperbaiki ventilasi, mensinkronkan kerja otot abdomen dan toraks (PDPI, 2016). Latihan PLB akan terjadi inspirasi kuat dan ekspirasi kuat serta memanjang. Ekspirasi yang dipaksa dan memanjang akan menurunkan resistensi pernafasan sehingga memperlancar udara yang dihirup atau dihembuskan (Khasanah, 2014). PLB menjadikan tekanan dalam rongga mulut yang akan dilanjutkan melewati percabangan bronkus sehingga terhindar dari air trapping serta kolaps pada saluran nafas kecil saat ekspirasi yang dapat meningkatkan FEV1 (Smeltzer et al., 2008). PLB dapat membantu pengosongan alveoli secara maksimal dan meningkatkan peluang masuknya oksigen kedalam ruang alveolus sehingga proses difusi dan perfusi berjalan dengan baik. Meningkatnya transfer oksigen ke jaringan dan otot-otot pernafasan akan menyebabkan metabolisme anaerob dan menghasilkan energi (ATP). Energi ini dapat meningkatkan kekuatan otot-otot pernafasan sehingga proses pernafasan dapat berjalan dengan baik yang akan mempengaruhi peningkatan arus puncak ekpirasi (Guyton et al, 2007).

Kontrol otot pernafasan PLB ketika inspirasi menyebabkan kenaikan volume tidal, 
menurunnya inspiratory flow rate dan jumlah pernafasan. Ventilasi alveolus akan meningkat serta membantu pompa jantung saat mengalirkan darah kesemua bagian tubuh. Berkurangnya sesak nafas menjadikan otot pernafasan menjadi lebih efektif dalam mengurangi kinerja pernafasan karena sedikit hilangnya energy, sehingga potensial menunda kelelahan (Alexandra, 2001). Penelitian ini di dukung oleh penelitian yang menerapkan PLB pada pasien emfisema yang mendapatkan perbedaan signifikan terhadap pola pernafasan sebelum dan sesudah dilakukan PLB (Astuti, 2014).

Penelitian Nield (2007) menunjukkan hasil latihan PLB lebih efektif menurunkan sesak nafas dari pada kelompok intervensi yang diberikan latihan dengan expiratory muscle training. Hasil penelitan Kim et al. (2012) menunjukan PLB signifikan meningkatkan tidal volume (TV) dan menurunkan pernafasan dibandingkan bernafas biasa. Penelitian Natalia (2007) efektifitas pursed lips breathing dan tiup balon pada pasien asma dilakukan $4 x$ sehari (dengan jarak 4-5 jam), masing masing 10 menit, selama 4 hari menunjukkan PLB dan tiup balon efektif meningkatkan nilai PEF.

Penelitian Dewi (2015) latihan PLB dilakukan pengulangan 6 kali dengan jeda 2 detik yang dilakukan selama 3 hari di dapatkan hasil pengaruh PLB terhadap peningkatan FEV1 pada penderita PPOK. Hasil penelitian yang berbeda adalah penelitian Visser et al. (2010) yang melakukan latihan PLB hanya dilakukan selama 5 menit. Hasil analisa menggunakan paired $t$ test di dapatkan hasil nilai $p=0.341$ berarti tidak ada pengaruh PLB yang hanya dilakukan selama 5 menit terhadap peningkatan nilai PEF.

Kelompok kontrol tidak diberikan latihan nafas ini sehingga tidak ada upaya dalam mengurangi jumlah air trapping pada paru-paru responden kelompok kontrol. Tidak adanya upaya dalam mengeluarkan air trapping dalam tubuh membuat peningkatan kadar PCO2 (hiperkapnia) sehingga membuat menurunnya kadar PO2 (hipoksemia), hal tersebut memicu terjadinya asidosis respiratorik. Hipoksia yang dihasilkan akibat terjadinya hipoksemia membuat terjadinya metabolisme anaerob sehingga memicu meningkatnya asam laktat yang menyebabkan terjadinya kelelahan otot saat bernafas. Kelelahan otot tersebut membuat aliran udara yang dikeluarkan saat ekspirasi akan menurun. Sehingga nilai PEF kelompok kontrol tidak terjadi perubahan yang signifikan.
2. Perbedaan selisih (delta) rata-rata nilai PEF sebelum dan setelah edukasi self management dan latihan PLB kelompok kontrol dan kelompok intervensi.

Berdasarkan hasil uji independent $t$ test didapatkan nilai $p=0.000$ yang menunjukkan adanya perbedaan selisih rata-rata nilai PEF kelompok kontrol dan kelompok intervensi sebelum dan sesudah edukasi self management dan latihan PLB. Peneliti berasumsi hasil ini dapat dipengaruh oleh pemberian edukasi self management, latihan PLB dan terapi obat yang tetap diberikan pada kelompok intervensi yaitu: Aminophilin $150 \mathrm{mg}$ $3 x$ sehari, salbutamol $2 \mathrm{mg} 3 x$ sehari, ambroxol $30 \mathrm{mg} 3 x$ sehari.

Latihan pernafasan dengan metode PLB pada kelompok intervensi yang teratur selama 4 minggu dapat meningkatkan tahanan udara dan kepatenan jalan nafas. Proses ini membantu menurunkan pengeluaran air trapping, sehingga dapat mengontrol ekspirasi dan memfasilitasi pengosongan alveoli secara maksimal (Aini, 2008). Ekspirasi yang dipaksa dan memanjang pada PLB akan memperlancar udara inspirasi dan ekspirasi sehingga mencegah terjadinya air trapping di dalam alveolus (Khasanah, 2013).

Adanya fasilitas pengosongan alveoli secara maksimal akan meningkatkan peluang masuknya oksigen kedalam ruang alveolus sehingga proses difusi dan perfusi berjalan dengan baik. Meningkatnya transfer oksigen ke jaringan dan otot-otot pernafasan akan menyebabkan metabolisme anaerob yang akan menghasilkan suatu energi (ATP). Energi ini dapat meningkatkan kekuatan otot-otot pernafasan sehingga proses pernafasan dapat berjalan dengan baik, dengan proses pernafasan yang baik akan mempengaruhi terhadap peningkatan arus puncak ekpirasi atau nilai PEF (Guyton et al, 2007).

Kontrol otot pernafasan pada PLB ketika inspirasi akan membantu dalam meningkatkan tidal volume, menurunnya inspiratory flow rate dan respiration rate. Penurunan frekuensi pernafasan ini dapat menambah efisiennnya ventilasi alveoli dan mengurangi beban kerja pompa jantung menuju tubuh. Penurunan frekuensi pernafasan membuat otot pernafasan menjadi lebih efektif karena tidak banyak energy yang terbuang, sehingga potensial menunda kelelahan (Alexandra, 2001).

Peningkatan nilai PEF juga dipengaruhi oleh pemberian terapi obat. Aminophilin merupakan obat untuk merangsang jantung dan merileksasikan otot halus. Obat ini dapat 
bekerja dalam pembuluh darah yang menimbulkan pengaruh terjadinya vasodilatasi dan pada bronkus dapat melebarkan saluran nafas (Ikawati, 2006). Mekanisme kerja aminophilin yaitu mencegah enzim fosfodiesterase dalam pemecahan cAMP dan cGMP masing-masing menjadi 5'-AMP dan 5'GMP. Proses ini mengakibatkan menumpuknya cAMP dan cGMP dalam sel dan terjadilah relaksasi otot polos, termasuk otot polos pada bronkus (Gunawan, 2007).

Obat yang juga mempengaruhi peningkatan nilai PEF yaitu salbutamol yang merupakan obat bronkodilator golongan agonis B2. Cara kerja obat ini yaitu menstimulasi reseptor B2 di trachea dan bronchus, sehingga terjadi aktivasi enzim adenilsiklase. Enzim ini dapat membantu perubahan adenosinetrifosfat (ATP) menjadi cyclic adenosine monophospate (cAMP) (Tjay dan Rahardja, 2007). Obat lainnya adalah ambroxol yaitu jenis mukolitik yang berguna untuk mengencerkan dahak dalam saluran nafas melalui pememecahan benang mukoprotein dan mukopolisakarida pada dahak (Estuningtyas, 2008). Obat ini dapat meringankan sesak napas pada serangan asma yang terjadi sumbatan lendir kental. Ambroksol merupakan metabolit aktif dari bromheksin yang dimetabolit di hati. Ambroksol merupakan metabolit yang stabil sehingga dapat mengurangi efek samping yang ditimbulkan oleh bromheksin (Tjay dan Raharja, 2002).

Penelitian ini di dukung oleh penelitian yang juga menerapkan latihan PLB untuk pasien emfisema yang mendapatkan perbedaan signifikan terhadap pola pernafasan sebelum dan sesudah dilakukan PLB (Astuti, 2014). Penelitian oleh Nield (2007) juga menunjukkan hasil bahwa latihan PLB lebih efektif menurunkan sesak nafas dari pada kelompok intervensi yang diberikan latihan dengan expiratory muscle training.

Hasil penelitian penelitan Kim et al. (2012) menunjukan bahwa pola bernafas PLB signifikan meningkatkan tidal volum (TV) dan menurunkan pernafasan dibandingkan bernafas biasa. Penelitian Jones, et al (2003) juga menunjukan PLB dapat meningkatkan tidal volume dan menurunkan pernafasan pada pasien PPOK. Penelitian Dewi (2015) dengan intrvensi PLB dilakukan selama 6 kali, jeda 2 detik saat pengulangan, dan dilakukan selama 3 hari didapatkan hasil pengaruh PLB terhadap peningkatan nilai FEV1 pada penderita PPOK.

Berdasarkan hasil ini peneliti berasumsi bahwa dengan dilakukannya edukasi dan latihan PLB menyebabkan ekspirasi secara paksa sehingga terjadi peningkatan kemampuan kontraksi otot intra abdomen yang akan meningkat melebihi fase ekspirasi keadaan ini dimana keadaan ini juga meningkatkan pergerakan diafragma ke atas yang menyebabkan rongga torak mengecil. Tekanan intra alveoli meningka melebihi tekanan udara atmosfir sehingga udara keluar dari paru-paru ke atmosfir. Keadaan ini juga akan menyebabkan sumbatan jalan nafas berkurang sehingga sesak nafas menurun, dan udara yang dihembuskan akan lancar.

Ekspirasi yang lebih lama dari inspirasi ini akan meningkatkan waktu difusi dan keseimbangan oksigen dikapiler darah paru dan alveolus. Kondisi ini juga menurunkan frekuensi pernafasan dan membantu mengeluarkan jebakan udara dalam paru sehingga memungkinkan udara bersih dapat masuk kedalam paru-paru. Penggunan obat juga membantu dalam meningkatkan Nilai PEF karena dengan pemberian obat bronkodilator mengakibatkan relaksasi otot polos bronkus yang dapat melebarkan saluran nafas. Pemberian mukolitik juga membantu dalam pengenceran sekret sehingga membantu responden untuk mengeluarkan sekret yang dapat melancarkan aliran udara dalam saluran nafas.

\section{KESIMPULAN}

1. Terdapat perbedaan rata-rata skor nilai PEF sebelum dan setelah latihan pursed lips breathing pada kelompok intervensi

2. Tidak terdapat perbedaan rata-rata skor nilai PEF pada kelompok kontrol.

3. Terdapat perbedaan selisih rata-rata nilai PEF latihan pursed lips breathing pada penderita PPOK.

4. Terdapat pengaruh latihan pursed lips breathing dalam meningkatkan nilai PEF pada penderita PPOK.

\section{SARAN}

1. Bagi Rumah Sakit

Penelitian ini dapat menjadi salah satu bahan edukasi dan intervensi keperawatan yang dapat diterapkan di rumah sakit sebagai standar prosedur operasional dalam penatalaksanaan pasien PPOK sehingga dapat berorientasi terhadap peningkatan kualitas hidup pasien PPOK.

2. Bagi Institusi Keperawatan

Penelitian ini bisa meningkatkan pengetahuan mahasiswa sehingga bisa 
diterapkan untuk asuhan keperawatan dalam meningkatkan kualitas hidup pasien PPOK

3. Bagi pasien PPOK

Melaksanakan self management dan latihan pursed lips breathing selama perawatan dirumah sehingga dapat membantu mengatasi masalah yang sering muncul agar dapat meningkatkan kualitas hidup.

4. Bagi Peneliti Selanjtnya

Pentingnya dilakukan penelitan kembali tentang edukasi self management latihan pursed lips breathing dengan kombinasi latihan nafas lainnya dan sampel lebih besar

\section{DAFTAR PUSTAKA}

Alexandra, H. 2001. Physiotherapy in Respiratory Care. United Kingdom: Nelson Thornes. p. 172

Ambrosino, N. et al (2006). Comprehensive Treatment of Dyspnoea in Chronic Obstructive Pulmonary Disease Patients. University Hospital of Pisa: Long Termhealth Care

Astuti, L. (2014). Pengaruh Pursed Lips Breathing (PLB) Terhadap Pola Pernapasa Pada Pasien Dengan Emfisema Di Rumah Sakit Paru Dr. Ario Wirawan Salatiga. http:// perpusnwu Web.id/karya ilmiah /documents/3837.pdf

Depkes (2008). Pedoman pengendalian Penyakit Paru Obstruktif Kronis (PPOK).

Dewi S.K (2015) Pengaruh Pursed Lips Breathing (PLB) Terhadap Nilai Forced Expiratory Volume In One Second (Fev1) Pada Penderita Penyakit Paru Obstruksi Kronis Di Rs Paru Dr Ario Wirawan Salatiga.

Gunawan (2007). Farmakologi dan terapi edisi 5. Departemen Farmakologi dan Terapeutik FKUI

Guyton A. (2007) Buku Ajar Fisiologi Kedokteran. Edisi 11. Jakarta : EGC

Karina (2016) Data rekam medis RSU Asy Syaafi Kabupaten Pamekasan. Profil penyakit paru obstruksi kronis tahun 2016

Khasanah, (2014). efektifitas posisi condong ke depan (CKD) dan pursed lips breathing (PLB) terhadap peningkatan saturasi oksigen pasien penyakit paru obstruktif kronik (PPOK). in prosiding seminar nasional \& internasional.

Kim et al. (2012). Effects of breathing maneuver and sitting posture on muscle activity in inspiratory accessory muscles in patients withchronic obstructive pulmonary disease. Multidisciplinary Respiratory Medicine.

Nield, (2007) Efficacy of Pursed-Lips Breathing

Natalia D, Saryono Dina Indrati (2007) Efektifitas pursed lips breathing dan tiup balon dalam peningkatan arus puncak ekspirasi (APE) Pasien asma bronchiale di RSUD Banyumas Perhimpunan dokter paru Indonesia (PDPI) (2016). Diagnosis dan penatalaksaan PPOK. Edisi 2006, Penerbit Universitas Indonesia

Price, et al (2005). Patofisiologi Konsep Klinis Proses-Proses Penyakit. Edisi 6, Vol. 2. Jakarta: EGC

Smeltzer. (2008). Buku Ajar Keperawatan Medikal Bedah Brunner \& Suddarth. Edisi 8 Volume 2. Alih Bahasa H. Y. Kuncara, Monica Ester,Yasmin Asih, Jakarta : EGC.

Tjay, Tan Hoan dan Kirana Rahardja, 2007, Obat-Obat Penting Khasiat, Penggunaan dan Efek-Efek Sampingnya, Edisi Keenam, 262, 269-271, PT. Elex Media Komputindo, Jakarta

Visser, F. J., Ramlal, S., Dekhuijzen, P. R., \& Heijdra, Y. F. (2010). Pursed-lips breathing improves inspiratory capacity in chronic obstructive pulmonary disease. Respiration, 81(5), 372-37 